\title{
A evolução da investigação em desporto na última década
}

\author{
The evolution of the sports research over the last decade
}

Tiago M. Barbosa, ${ }^{1^{*}}$

EDITORIAL | EDITORIAL

Existe a ideia generalizada entre a maioria dos académicos e investigadores que nos últimos cinco a dez anos se tem verificado uma evolução particularmente acentuada da produção científica em Desporto, Educação Física e áreas afins. Com todas as limitações que lhe estão associadas, existem vários indicadores bibliométricos que são recorrentemente selecionados para uma análise mais aprofundada.

Considere-se para o efeito o Web of Scien$c e{ }^{\circledR}$ de 02 de Junho de 2015. Entre o ano de 2005 e Junho de 2015 foram publicados 67031 trabalhos na área do Desporto, o que daria uma média de praticamente 6700 artigos por ano, ou de uma forma mais prosaica, 18.35 artigos por dia, 0.76 artigos por hora. Pese embora dizer que se publica praticamente um trabalho em Desporto por hora em revista de topo, parecer um tanto demagógico; não deixa de também ser uma boa forma de demonstrar como a investigação a nível internacional se tornou tão competitiva.

Faça-se de seguida a análise por países com maiores níveis de produtividade. Em primeiro lugar surge os Estados Unidos da América (15735, 23.47\%), seguido da Inglaterra (5961, $8.89 \%$ ) e fecha o "pódio" a Austrália (4644, $6.92 \%)$. O Brasil aparece em oitavo lugar (2075, 3.09\%) e Portugal em décimo sétimo (778, 1.16\%). Apenas para haver um melhor entendimento da evolução que tem ocorrido, o Brasil passou de sensivelmente 50 artigos no ano de 2005 para pouco mais de 350 em 2014 e Portugal de pouco menos de 20 para 160. A título ilustrativo, Inglaterra em 2005 teve pouco menos de 300 trabalho publicados e em 2014 quase 800 . Ou seja, com base nestes in- dicadores dir-se-ia que os dois países lusófonos têm vindo a diminuir a distância em comparação com países anglo-saxónicos com maior tradição académica. Claro que há fatores que não estão a ser tomados aqui em consideração para além da dita "tradição", tais como, investimento público e privado em Ensino, Ciência $\&$ Tecnologia quer em valor absoluto quer em termos relativos do PIB, percentagem da população a frequentar o sistema de ensino terciário, etc.

Mas como tocamos no assunto dos países lusófonos versus os anglo-saxónicos, talvez a comparação entre grupos de países com uma mesma matriz socio-cultural e linguística possa ser interessante. Os países anglo-saxónicos produziram 29643 dos trabalhos (44.22\%), os lusófonos 3052 (4.55\%), os francófonos 2937 (4.38\%), os hispânicos 2633 (3.92\%) e os eslavos $666(0.9 \%)$. Repare-se que países que estão na base do que são hoje as Ciências do Desporto, como os do leste da Europa, tem-se vindo a afastar da liderança. Muitos dos fundamentos em Psicologia, Fisiologia, Biomecânica ou Treino Desportivo tiveram origem em autores do Leste da Europa. Provavelmente nestes países continuam a existir investigadores com elevadas competências e produzir conhecimento útil. Contudo, este não chega aos chamados países ocidentais porque a sua difusão não é feita numa língua de fácil entendimento para não-eslavos.

Voltando aos indicadores bibliométricos mas ponderando a língua adotada para comunicar os resultados da investigação. Entre 2005 e 2015,51916 (77.45\%) trabalhos foram publicados em língua inglesa. O coreano foi usa-

\footnotetext{
${ }^{1}$ Editor Chefe da Revista Motricidade; Physical Education \& Sports Science Academic Group, National Institute of Education, Nanyang Technological University

*NIE5-03-31, 1 Nanyang Walk, Singapore; Email: editor.in.chief@revistamotricidade.com
} 


\section{2| TM Barbosa}

do em 9334 (13.92\%) e o Português em 1269 (1.89\%) entradas na $W e b$ of Science ${ }^{\circledR}$ nessa década. Ciência é sinónimo de produção de conhecimento, mas também da sua difusão e partilha com os pares. Repare-se que o coreano é a segunda língua mais utilizada, mas com uma média de citações por trabalho de 0.01 (índex $\mathrm{H}$ de 04), além que o país se encontra em $22^{\circ}$ lugar do ranking. Indubitavelmente, após a segunda guerra mundial, o inglês tornou-se a língua franca da Ciência. Este não é espaço para explicar o motivo para que tal tenha acontecido, mas é dado incontornável. Para que um trabalho tenha uma maior exposição, terá de ser comunicado num língua que a larga maioria dos pares entenda.

Foi com base nestes factos que foi decidido que a Revista Motricidade tem de acompanhar a realidade atual caso se queira manter como publicação de referência. Portanto, em breve uma das regras de submissão de trabalhos será alterada. Manter-se-á a premissa que o aspeto determinante na avaliação do trabalho é o rigor metodológico e a definição do problema científico em causa. Contudo, num mundo global como aquele em que vivemos hoje, não se pode ignorar que de pouco serve publicar trabalhos de qualidade se depois não são entendíveis por autores que não dominem o português. Assim, a partir de Janeiro de 2016 os trabalhos submetidos à Revista Motricidade terão de ser redigidos em língua inglesa. Os trabalhos em língua portuguesa entretanto aceites serão publicados nos próximos números e os que se encontrem em processo de revisão continuarão a ser tomados em consideração.

Todo o conteúdo da revista Motricidade está licenciado sob a Creative Commons, exceto quando especificado em contrário e nos conteúdos retirados de outras fontes bibliográficas. 